\title{
Influence of transcervical infusion of seminal plasma on the farrowing rate and litter size in artificially inseminated sows
}

\author{
[Influência da infusão transcervical de plasma seminal na taxa de partos e tamanho \\ da ninhada em porcos inseminados artificialmente] \\ I. Stančić ${ }^{1}$, I. Radović ${ }^{1}$, S. Dragin ${ }^{1}$, M. Mirkov ${ }^{1}$, I. Pihler ${ }^{1}$, \\ M.P. Horvatovic ${ }^{1 *}$, J. Apic ${ }^{2}$, I. Zdraveski ${ }^{3}$ \\ ${ }^{1}$ Faculty of Agriculture - University of Novi Sad - Novi Sad, Serbia \\ ${ }^{2}$ Scientific Veterinary Institute Novi Sad - Novi Sad, Serbia \\ ${ }^{3}$ Faculty of Veterinary Medicine - Bitola, Republic of Macedonia
}

\begin{abstract}
Recent studies have focused on the use of seminal plasma to increase sow fertility after classical intracervical artificial insemination (AI). The aim of the present study was to investigate the influence of seminal plasma infusion, prior to the application of conventional AI dose, on the fertility rate in sows. A total of 114 sows were treated with intrauterine infusion of $30 \mathrm{ml}$ seminal plasma (SP), while 114 control sows were infused by physiological solution (PS), immediately before the application of conventional AI dose. The experiment was conducted at one commercial pig farm in Serbia, which is comprised of 1,500 sows in the breeding herd. Intrauterine infusion of seminal plasma produced significantly $(\mathrm{P}<0.05)$ higher farrowing rate $(93.8 \%)$ and significantly $(\mathrm{P}<0.01)$ more live-born piglets per litter $(12.27)$, compared with the control sows $(83.33 \%$ farrowing rate and 10.48 piglets). The present results show that intrauterine infusion of seminal plasma can be a useful tool for increasing the fertility rate in artificially inseminated sows, under the conditions of practical intensive pig production.
\end{abstract}

Keywords: seminal plasma, infusion, AI, fertility, sows

\section{RESUMO}

Estudos recentes concentraram no uso de plasma seminal para aumentar a fertilidade de porcos após inseminação artificial intracervical clássica (AI). O objetivo do presente estudo foi investigar a influência da infusão de plasma seminal, antes da aplicação da dose de AI convencional, na taxa de fertilidade de porcas. 114 porcas foram tratadas com infusão intrauterina de $30 \mathrm{ml}$ plasma seminal, e 114 porcas de controle receberam infusão de solução fisiológica (PS) imediatamente antes da aplicação da dose convencional de AI. O experimento foi realizado em uma fazenda de porcos comercial na Serbia, que é composta de 1.500 porcas no rebanho de reprodução. A infusão intrauterina de plasma seminal produziи uта taxa de fertilidade (93,8\%) significativamente maior $(P<0.05)$, e significativamente mais $(P<0.01)$ leitões nascidos vivos por ninhada $(12,27)$ comparado com as porcas de controle $(83,33 \%$ taxa de fertilidade e 10,48 leitões). Os resultados mostram que infusão intrauterina com plasma seminal pode ser uma ferramenta útil para aumentar a taxa de fertilidade em porcas inseminadas artificialmente, sob as condições de prática de produção intensiva de porcos.

Palavras-chave: plasma seminal, infusão AI, fertilidade, porcas

\section{INTRODUCTION}

In most European countries, diluted liquid semen in the dose volume of $80 \mathrm{ml}$, with average $3 \times 10^{9}$ motile spermatozoa are used for conventional intracervical artificial insemination (Roca et al.,

Recebido em 18 de dezembro de 2018

Aceito em 12 de agosto de 2019

*Autor para correspondência (corresponding author)

E-mail:dr.ivan.stancic@gmail.com
2001; Stančić et al., 2009; Khalifa et al., 2014). On average, a single boar produces about 20 doses per ejaculate, or 1,200 of such insemination doses annually. This means that a certain number of ejaculates must be overdiluted (Singelton, 2004; Stančić et al., 2009). 
However, using overdiluted AI doses is frequently recognized as a reason for reduced fertility in artificially inseminated sows (Gadea, 2005; Alm et al., 2006). Namely, it has been found that over dilution of seminal plasma, for example in overdiluted AI doses, leads to significant reduction of spermatozoa fertility (Kommisrud et al., 2002; Maxwell et al., 2007; Stančić et al., 2012). In addition, ejaculate over dilution decreases the concentration of bioactive components in the seminal plasma, which influences the physiological processes important for successful transport and function of spermatozoa, as well as successful fertilization and embryo development in the female reproductive tract (Robertson, 2005, 2007; Rodríguez-Martínez et al., 2011; Jalali et al., 2014).

Recently, it has been shown that intrauterine infusion of natural (Waberski et al., 1996; Capitan et al., 2006, Kirkwood et al., 2008; Okazaki et al., 2012) or synthetic seminal plasma (Predil MR-A ${ }^{\circledR}$ ) (Lyczynski et al., 2000; Martin Rillo et al., 1996; Garcia Ruvalcaba et al., 2009; Dimitrov, 2012; Stančić et al., 2014), prior to the application of conventional AI dose, increases the farrowing rate and litter size in artificially inseminated sows. Therefore, the objective of this study was to evaluate the influence of natural seminal plasma infusion - prior to the application of conventional AI dose - on the fertility rate in sows in the conditions of Serbian intensive pig production.

\section{MATERIAL AND METHODS}

Farm and animals. The experiment was conducted at one commercial pig farm in Serbia, with 1,500 Swedish Landrace sows in the breeding herd, in terms of the regular production cycle. In the year 2014/2015, the average farrowing rate on the farm was $78.6 \%$, with 10.57 live-born piglets per liter. Until AI, the weaned sows were housed in open group pens. Classical artificial insemination (AI) was performed. After AI, the sows stayed in crates for 30 days, and then they were moved to open group pens. Detections of rebreeding (return to estrus after AI) were performed daily, by full contact with a teaser boar, starting on day 14 after AI. About 5 to 7 days before the expected farrowing, the pregnant sows were relocated to individual farrowing pens. Lactation lasted for 28 days.

Since this is research in which only biological material was used, an Ethics Committee was not taken into consideration since the animals used in the research were in the regular intensive production process, from which only written results at end of the reproductive cycle were used.

Experimental sows. The sows used in the experiment included 228 second to fifth farrowing parity Swedish Landrace sows, in which the estrus was detected on the fourth or fifth day after weaning. A total of 228 sows were divided into two groups (114 in each group): treated sows and untreated sows, i.e. the control group. Both groups were equal in parity, body condition, health status and the number of weaned piglets per litter in the previous reproductive cycle.

Seminal plasma preparation. Two Swedish Landrace boars, with a similar fertility rate (litter size and farrowing rate) in the previous exploitation period, were used for seminal plasma obtained and sow insemination. The ejaculates were collected once a week, within the experimental period. The volume, concentration, progressive motility and total sperm number were detected for each ejaculate, immediately after the collection. The ejaculates used for the experiment were only those with minimal $120 \mathrm{ml}$ volume, minimal $200 \times 10^{6}$ sperm concentration $/ \mathrm{ml}$ and minimal $65 \%$ progressive motility. After quality evaluation, ejaculates were centrifuged at $3000 \times g$ for 15 minutes, at $4^{\circ} \mathrm{C}$. The obtained seminal plasma was divided into aliquots of $30 \mathrm{ml}$, placed in plastic flasks with caps, and stored in a freezer at $-20^{\circ} \mathrm{C}$.

Experimental procedure. Estrus was detected by full contact with a teaser boar, two times a day (07h and $17 \mathrm{~h}$ ), starting about $24 \mathrm{~h}$ after weaning. After collection and evaluation of standard semen parameters, fresh ejaculates were diluted with BTS medium extenders (Minitübe, Germany), in an average 1:4 proportion. On average, $15 \mathrm{AI}$ doses $\left(80 \mathrm{ml}\right.$ with $3 \times 10^{9}$ progressive motile spermatozoa) were obtained per ejaculate. Average ejaculate volume was $250 \mathrm{ml}$, total spermatozoa number was $60 \times 10^{9}$, and progressive motility was at least $75 \%$. The 
boars were equally used for insemination of the treated sows and the control group of sows.

The frozen seminal plasma doses were thawed in a refrigerator at $4^{\circ} \mathrm{C}$, starting about 24 hours before the start of AI. Immediately before the start of $\mathrm{AI}$, the thawed $30 \mathrm{ml}$ seminal plasma doses, conventional liquid AI doses and physiological solution were warmed at $35^{\circ} \mathrm{C}$ in a water bath for 30 minutes. Conventional intracervical AI was performed in the 114 experimental sows (treated with seminal plasma) and 114 control (untreated) sows. Insemination of all sows was done with catheters SafeBlue ClearGlide with PC Cannula- (Minitübe, Germany).

Insemination was performed by the same boars whose ejaculates were used for preparation of seminal plasma. Immediately before the conventional application of AI dose, the experimental (treated) sows were treated with intrauterine infusion via intracervical catheter for post cervical insemination with $30 \mathrm{ml}$ seminal plasma (both at first and second AI). The control sows were infused with $30 \mathrm{ml}$ physiological solution (both at first and second AI). The sows were first inseminated 12 hours after estrus detection, and secondly 24 hours after estrus detection. Return to estrus (rebreeding) was detected twice a day by full contact with a teaser boar, starting on day 14 after AI.

Statistical analysis. All data were analyzed using Group $T$-test (statistical analysis systems, package version "Statistics 12"), and presented as mean values \pm standard deviations (SD). Farrowing rates (\%) were analyzed using the Kruskal-Wallis Test (non-parametric). Average live-born piglets per litter were analyzed by using the Group $T$-test. A value of $\mathrm{P}<0.05$ was considered to be statistically significant.

\section{RESULTS}

The relationship between the intrauterine seminal plasma and the farrowing rates is shown in Table 1. The sows treated with intrauterine infusion of $30 \mathrm{ml}$ seminal plasma, prior to conventional AI dose application, have significantly $(\mathrm{P}<0.05)$ higher farrowing rate $(93.8 \%)$, compared with the control (untreated) sows (83.33\%). A significantly $(\mathrm{P}<0.01)$ larger number of pigs born alive per litter (12.27) were obtained in the sows infused by seminal plasma than in the control sows (10.48) (Table 2).

Table 1. Farrowing rate in the sows after infusion of seminal plasma* $(\bar{x} \pm \mathrm{SD})$

\begin{tabular}{ccccc}
$\begin{array}{c}\text { Sows } \\
\text { group }\end{array}$ & Treatment & $\begin{array}{c}\text { Sows } \\
\text { inseminated } \\
(\mathrm{n})\end{array}$ & $\begin{array}{c}\text { Sows } \\
\text { farrowed } \\
(\mathrm{n})\end{array}$ & $\begin{array}{c}\text { Farrowing rate } \\
(\%)\end{array}$ \\
\hline Treated & 30ml seminal plasma + AI dose & 114 & 107 & $93.80 \pm 0.24^{\mathrm{a}}$ \\
Control & 30ml physiological solution + AI dose & 114 & 95 & $83.33 \pm 0.37^{\mathrm{b}}$ \\
\hline *
\end{tabular}

*Seminal plasma (treated sows) or physiological solution (control sows) were infused immediately before conventional AI dose. AI dose: volume $80 \mathrm{ml}$ with $3 \times 10^{9}$ progressive motile spermatozoa.

${ }^{\text {ab }}$ Within a column, means without a common superscript differ $(\mathrm{P}<0.05)$.

Average number of dead-born piglets per litter was not significantly different $(\mathrm{P}>0.05)$ between the treated $(0.71)$ and the control sows $(0.85)$ and, consequently, total born piglets per litter was significantly $(\mathrm{P}<0.01)$ different between the treated (12.98) and the control sows (11.33) (Table 2).

Table 2. Litter size in the sows after transcervical infusion of seminal plasma $(\bar{x} \pm \mathrm{SD})$

\begin{tabular}{|c|c|c|c|c|c|}
\hline \multirow[b]{2}{*}{ Group } & \multirow[b]{2}{*}{ Treatment } & \multirow{2}{*}{$\begin{array}{c}\text { Sows } \\
\text { inseminated } \\
\text { (n) }\end{array}$} & \multicolumn{3}{|c|}{ Litter size at farrowing (n) } \\
\hline & & & live & dead & total \\
\hline Treated & $30 \mathrm{ml}$ seminal plasma & 114 & $12.27 \pm 2.49^{\mathrm{A}}$ & $0.71^{\mathrm{a}}$ & $12.98^{\mathrm{A}}$ \\
\hline Control & $30 \mathrm{ml}$ physiological solution $+\mathrm{AI}$ dose & 114 & $10.48 \pm 1.56^{\mathrm{B}}$ & $0.85^{\mathrm{a}}$ & $11.33^{\mathrm{B}}$ \\
\hline
\end{tabular}




\section{DISCUSSION}

Our results clearly show that intrauterine infusion of $30 \mathrm{ml}$ of natural seminal plasma, immediately prior conventional AI dose (volume of $80 \mathrm{ml}$ with $4 \times 10^{9}$ spermatozoa) application, provides significantly $(\mathrm{P}<0.05)$ higher farrowing rate $(93.8 \%)$ and live-born piglets per litter (12.27) $(\mathrm{P}<0.01)$, compared with the control (untreated) sows $(83.33 \%$ farrowing rate and 10.48 live-born piglets). Thus, in comparison with the control sows, intrauterine infusion of seminal plasma produced significantly $(\mathrm{P}<0.05)$ higher farrowing rate by $10.47 \%$, and significantly $(\mathrm{P}<0.01)$ more (aver. 1.79) liveborn piglets per litter.

The findings of the present study confirm the results of previous studies in that intrauterine infusion of natural seminal plasma increases the fertility rate in sows (Waberski et al, 1997; Capitan et al., 2006; Kirkwood et al., 2008; Okazaki et al., 2012; Waberski et al., 1996). An improvement has been reported in both litter size and farrowing rate in gilts with transcervical infusion by seminal and spermatozoa antigens (Murray et al., 1983) or by boar semen with killed spermatozoa, prior to regular breeding (Riley, 1999).

Certain authors (Capitan et al., 2006) found significantly $(\mathrm{P}<0.05)$ higher average number of piglets born alive (12.75 piglets/litter) compared to the control gilts (10.50 piglets), after intrauterine infusion of boar seminal plasma with killed spermatozoa before insemination. Intrauterine infusion of seminal plasma at the beginning of estrus results in significantly $(\mathrm{P}<0.05)$ higher farrowing rate $(93 \%)$ and liveborn piglets per litter (12.72), compared with the control sows $(88.8 \%$ and 10.41 piglets) (Bortolozzo et al., 2000). The results of other authors (Stahlberg et al., 2001) also demonstrate that transcervical intrauterine infusion of seminal plasma produces significantly higher $(\mathrm{P}<0.05)$ farrowing rate in sows (100\%) and live-born piglets per litter (13.03), compared with the control sows (93.3\% and 12.20 live-born piglets) (Stahlberg et al., 2001). These results are very similar to the results in the present study.

Compared with natural mating, when full ejaculate is deposited into the female reproductive tract, artificial insemination involves the deposition of diluted AI dose, with a greatly reduced spermatozoa number and seminal plasma amount (Okazaki et al., 2012). Unfortunately, it has been shown that using preserved extensively diluted boar semen for artificial insemination of sows often results in lower fertility rates, compared with natural mating (Tummaruk et al., 2000; Gadea, 2005; Alm et al., 2006; Stančić et al., 2009; Tanavots et al., 2012). This evidence suggests that bioactive substances in seminal plasma play an active role in the physiological processes important for sperm function in vitro and in vivo, fertilization, and embryo development in the female reproductive tract (Strzežek et al., 2005; Nasrin and Calogero, 2012; Okazaki et al., 2012).

Namely, it has been found that overextended seminal plasma reduces the progressive motility of sperm and increases the number of spermatozoa with damaged acrosome and/or disintegrated acrosomal membrane (Kommisrud et al., 2002; Maxwell et al., 2007; Novak et al., 2010; Stančić et al., 2012). It has also been demonstrated that seminal plasma influences the spermatozoa transport, survival and fertilization capacity in the female reproductive tract (Waberski et al., 2000; Rozeboom et al., 2000; Strzežek et al., 2005; Chutia et al., 2014).

Seminal plasma suppresses the immune response of the uterus against spermatozoa antigens (Waberski et al., 2000; Robertson and Sharkey, 2001; Langendijk et al., 2002; O'leary et al., 2004, 2006). Furthermore, some component(s) of seminal plasma advance ovulation and thus improve the chance for successful fertilization (Waberski et al., 1997; Madej et al., 2013). And finally, seminal plasma affects important physiological mechanisms in uterus for embryomaternal interactions and establishment of successful pregnancy (Waberski et al., 2000; Robertson and Sharkey, 2001; O'leary et al., 2002; Robertson, 2005, 2007; Jalali et al., 2014).

It has been shown that specific proteins of seminal plasma (particularly spermadhesins) play a key role in the above-mentioned processes (Töpfer-Petersen et al., 1998; Bortolozzo et al., 2000; Centurion et al., 2003; Jonáková and Tichá, 2004; Caballero et al., 2008; Garcia et al., 2009; Kaczmarek et al., 2013). It has been found that ejaculates with the highest protein 
levels in seminal plasma exhibited the highest fertility rates, compared with ejaculates with lower protein levels (Flowers, 2001; Mogielnicka-Brzozowska and Kordan, 2011)

Some results demonstrate positive correlations between the fertility rate and concentrations of the two specific seminal plasma proteins (Mogielnicka-Brzozowska and Kordan, 2011). Namely, ejaculates with the highest concentration of these proteins produce the highest farrowing rates $(86.7 \%)$ and the largest number of live-born pigs (11.2), compared to those with lower concentration of these proteins (78.4\% and 9.5 piglets born alive). According to these data, the author concluded that quantification of these two proteins in seminal plasma can be used for development of semen fertility tests for boars.

\section{CONCLUSION}

The obtained results in the present study demonstrate that transcervical intrauterine infusion of seminal plasma, prior to application of conventional AI dose, improves sow fertility (farrowing rate and litter size), under the conditions of practical Serbian pig production. Additionally, the results of the present study support the opinions of other authors that by using this procedure it is possible to decrease the negative impact of insemination with overdiluted AI doses. This provides an opportunity to increase the number AI doses per ejaculate and per boar anually. Consequently, reproductive exploitation of genetically superior boars can be significantly improved.

\section{REFERENCES}

ALM, K.; PELTONIEMI, T.A.O.; KOSKINEN, E.; ANDERSSON, M. Porcine field fertility with two different insemination doses and the effect of sperm morphology. Reprod. Domest. Anim., v.41, p.210-213, 2006.

BORTOLOZZO, P.F.; WENTZ, I.; BRANDT, G.; GUIDONI, A.L. Reproductive performance of sows submitted to uterine infusions. Pesqui. Agropecu. Bras., v.35, p.623-629, 2000.

CABALLERO, I.; VAZQUEZ, J.M.; GARCIA, E.M. et al. Major proteins of boar seminal plasma as a tool for biotechnological preservation of spermatozoa. Theriogenology, v.70, p.1352-1355, 2008.
CAPITAN, S.S.; PEÑALBA, F.F.; GEROMO, F.B.; DALUMPIENES, M.J. Improved reproductive efficiency in gilts by intrauterine infusion of killed boar semen before breeding. Asian-Austral. J. Anim. Sci., v.19, p.789-792, 2006.

CENTURION, F.; VAZQUEZ, J.M.; CALVETE, J.J. et al. Influence of porcine spermadhesins on the susceptibility of boar spermatozoa to high dilution. Biol. Reprod., v.69, p.640-646, 2003.

CHUTIA, T.R.K.; BISWAS, M.K.; TAMULI, B.C. et al. Effect of holding of semen and washing of seminal plasma on quality and fertility of Hampshire boar semen preserved at liquid state. Anim. Reprod. Sci., v.145, p.141149, 2014.

DIMITROV, S. Postcervical artificial insemination of sows in combination with synthetic seminal plasma (Predil MR-A ${ }^{\circledR}$ ). Contemp. Agric., v.61, p.169-174, 2012.

FLOWERS, W.L. Relationship between seminal plasma proteins and boar fertility. Swine News, v.6, p.1-4, 2001.

GADEA, J. Sperm factors related to in vitro and in vivo porcine fertility. Theriogenology, v.63, p.431-444, 2005.

GARCIA RUVALCABA, J.A.; PALLAS ALONSO, R.; HERNANDEZ-GIL, R.; DIMITROV, S. The use of synthetic seminal plasma (Predil MR-A ${ }^{\circledR}$ ) as a method to facilitate procedures with cervical and post-cervical artificial insemination of sows. Agric. Sci. Technol., v.1, p.2-7, 2009.

GARCIA, E.M.; CALVETE, J.J.; SANZ, L. et al. Distinct effect of boar seminal plasma fractions exibiting different protein profiles on the functionality of highly diluted boar spermatozoa. Reprod. Domest. Anim., v.44, p.200-205, 2009.

JALALI, M.B.; KITEWSKA, A.; WASIELAK, M.; BODEK, G.; BOGACKI, M. Effects of Seminal Plasma and the Presence of a Conceptus on Regulation of Lymphocyte-Cytokine Network in Porcine Endometrium. Mol. Reprod. Devel., v.81, p.270-281, 2014. 
JONÁKOVÁ, V.; TICHÁ, M. Boar seminal plasma proteins and their binding properties (a review). Collect. Czech Chem. Commun., v.69, p.461-475, 2004.

KACZMAREK， M.; KRAWCZYNSKI， K.; FILANT, J. Seminal plasma affects prostaglandin synthesis and angiogenesis in the porcine uterus. Soc. Study Reprod., v.6, p.1-21, 2013.

KHALIFA, T.; REKKAS, C.; SAMARTZI, F. et al. Highlights on artificial insemination (AI) technology in the pigs. Macedonian Vet. Rev., v.37, p.5-34, 2014.

KIRKWOOD, N.R.; VADNAIS, M.L.; ABAD, M. Practical application of seminal plasma. Theriogenology, v.70, p.1364-1367, 2008.

KOMMISRUD, E.; PAULENZ, H.; SEHESTED, E.; GREVLE, S.I. Influence of boar and semen parameters on motility and acrosome integrity in liquid boar semen stored for five days. Acta Vet. Scand., v.43, p.49-55, 2002.

LANGENDIJK, P.E.G.; BOUWMAN, N.M.; SOEDE, M.A.M. et al. Role of myometrial activity in sperm transport through the genital tract and in fertilization in sows. Reproduction, v.123, p.663-690, 2002.

LYCZYNSKI, A.; SOCZYWKO, T.; MARTIN RILLO, S.; ALBA ROMERO, C. The effect of Predil MR-A synthetic seminal plasma used to inseminate sows and gilts on their reproductive efficiency. In: INTERNATIONAL CONFERENCE ON BOAR SEMEN PRESERVATION, 4., 2000, Beltsville. Proceedings... Beltsville: Royal College Physicians, 2000. (Abstract).

MADEJ, M.; HANSEN, C.; JOHANNISSON, A.; MADEJ, A. Heparin-binding proteins from boar seminal plasma affecting the release of prostaglandins and interleukin- 6 by porcine endometrial and cervical cells and bovine endometrial cells. Nat. Sci., v.5, p.21-30, 2013.

MARTIN RILLO, S.; LAPUENTE, S.; HERNANDEZ-GIL, R. et al. Improvement of fertility results by means of usage of synthetic seminal plasma before artificial insemination. In: INTERNATIONAL PIG VETERINARY SOCIETY CONGRESS, 14., 1996, Bologna. Proceedings... Bologna, Italy: 1996. p.605. (Abstract).
MAXWELL, W.M.C. GRAAF, P.S.; GHAOUI, E.H.R.; EVANS, G. Seminal plasma effects on sperm handling and female fertility. Soc. Reprod. Fertil., v.64, p.13-38, 2007.

MOGIELNICKA-BRZOZOWSKA, M.; KORDAN, W. Characteristics of selected seminal plasma proteins and their application in the improvement of the reproductive processes in mammals (Review). Pol. J. Vet. Sci., v.14, p.489-499, 2011.

MURRAY, F.A.; GRIFO, A.P.J.R.; PARKER, C.F. Increased litter size in gilts by intrauterine infusion of seminal and sperm antigens before breeding. J. Anim. Sci., v.56, p.895-900, 1983.

NASRIN, S.J.; CALOGERO, S. Seminal plasma: an essential attribute to spermatozoa (a review). J. Androl., v.33, p.536-551, 2012.

NOVAK, S.; RUIZ-SANCHEZ, A.; DIXON, T.W.; FOXCROFT, G.R.; DYCK, M.K. Seminal plasma proteins as potential markers of relative fertility in boars. J. Androl., v.31, p.188-200, 2010.

O'LEARY, S.; JASPER, J.M.; ROBERTSON, A.S.; ARMSTRONG, T.D. Seminal plasma regulates ovarian progesterone production, leukocyte recruitment and follicular cell responses in the pig. Reproduction, v.132, p.147158, 2006.

O'LEARY, S.; ROBERTSON, A.S.; DAVID, T.; ARMSTRONG, T.D. The influence of seminal plasma on ovarian function in pigs - a novel inflammatory mechanism? J. Reprod. Immunol., v.57, p.225-238, 2002.

O'LEARY, S.M.J.; JASPER, G.M.; WARNES, D.T. et al. Seminal plasma regulates endometrial cytokine expression, leukocyte recruitment and embryo development in the pig. Reproduction, v.128, p.237-247, 2004.

OKAZAKI, T.; AKIYOSHI, T.; KAN, M. et al. Artificial insemination with seminal plasma improves the reproductive performance of frozen-thawed boar epididymal spermatozoa. $J$. Androl., v.33, p.990-998, 2012.

RILEY, J. Uterine priming of gilts to increase litter size. [s.1.]: Associates International, 'Warreners', 1999. (MS 150, Pittsworth Qld 4356). 
ROBERTSON, S.A. Seminal fluid signaling in the female reproductive tract: lessons from rodents and pigs. J. Anim. Sci., v.85, Suppl. 13, p.E36-E44, 2007.

ROBERTSON, S.A. Seminal plasma and male factor signalling in the female reproductive tract (review). Cell Tissue Res., v.322, p.43-52, 2005.

ROBERTSON, S.A.; SHARKEY, J.D. The role of semen in induction of maternal immune tolerance to pregnancy. Semin. Immunol., 13: 243-254, 2001.

ROCA, J.; PARRILLA, I.; RODRIGUEZMARTINEZ, H. et al. Approaches towards efficient use of boar semen in the pig industry. Reprod. Domest. Anim., v.46, Suppl.2, v.79-83, 2001.

RODRÍGUEZ-MARTÍNEZ, H.; KVIST, U.; ERNERUDH, SANZ, L.; CALVETE, J.J. Seminal plasma proteins: what role do they play? Am. J. Reprod. Immunol., v.66, p.11-22, 2011.

ROZEBOOM, K.J.; TROEDSSON, M.H.; HODSO,N H.H.; SHURSON, G.C.; CRABO, B.G. The importance of seminal plasma on the fertility of subsequent artificial inseminations in swine. J. Anim. Sci., v.78, p.443-448, 2000.

SINGELTON, W.L. State of the art in artificial insemination in the Uniteted States. Theriogenelogy, v.56, p.1305-1310, 2001.

STAHLBERG, R.; BORTOLOZZO, F.P.; WENTZ, I. et al. Influência da infusão transcervical de plasma seminal ou de estrógeno na concepção, no ciclo estral e na ovulação de porcas [Influence of transcervical infusion of seminal plasma or oestrogen on conception, estrus cycle and ovulation in sows]. Arq. Bras. Med. Vet. Zootec., v.53, p.323-329, 2001.

STANČIĆ, B.; GRAFENAU, P.; RADOVIĆ, I.; PETROVIĆ, M.; BOŽIĆ, A. Intensity of boar sperm utilization in Vojvodina and possibility of its increase. Contemp. Agric., v.58, p.19-26, 2009.

STANČIĆ, I.; DRAGIN, S.; STANKOVIĆ, B.; JOTANOVIĆ, S. Effect of protein contents in seminal plasma on sperm motility in diluted boar semen. In: INTERNATIONAL SYMPOSIUM ON ANIMAL SCIENCE, 2012, Belgrade. Proceeding... Belgrade: [s.n.], 2012. p.149-154.
STANČIĆ, I.; RADOVIĆ, I.; ERDELJAN, M. et al. Sow Fertility After Intracervical AI in Cool and Warm Seasons Using Conventional Doses in Combination with Synthetic Seminal Plasma (Predil Mra ${ }^{\circledR}$ ). Contemp. Agric., v.63, p.29-35, 2014.

STRZEŽEK, J.; WYSOCKI, P.; KUKLINSKA, M. Proteomiks of boar seminal plasma - current studies and possibility of their application in biotechnology of animal reproduction. Reprod. Biol., v.5, p.279-290, 2005.

TANAVOTS, A.; KAART, T.; SAVELI, O. Artificial insemination in pig breeding in Estonia. Vet. Zootec., v.19, p.109-111, 2002.

TOPFER-PETERSEN, E.; ROMERO, A.; VARELA, P.F. et al. Spermadhesins a new protein family: facts, hypotheses and perspectives. Andrologia, v30, p.217-224, 1998.

TUMMARUK, P.; LUNEHEIM, N.; EINARSSON, S.; DALIN, A.M. Reproductive performance of purebred Swedish Landrace and Swedish Yorkshire sows: II. Effect of mating type, weaning-to-first-service interval and lactation length. Acta Agric. Scand. A Anim. Sci., v.50, p.217-224, 2000.

WABERSKI, D.; CLAASSEN, R.; HAHN, T. et al. LH profile and advancement of ovulation after transcervical infusion of seminal plasma at different stages of estrus in gilts. J. Reprod. Fertil., v.109, p.29-34, 1997.

WABERSKI, D.; SOARES, G.A.J.; ARRUDA, B.E.; WEITZE, F.K. Effect of a transcervical infusion of seminal plasma prior to insemination on the fertilizing competence of low numbers of boar spermatozoa at controlled AI-ovulation intervals. Anim. Reprod. Sci., v.44, p.165-173, 1996.

WABERSKI, D; TÖPFER-PETERSEN, E.; WEITZE, K.F. Does seminal plasma contribute to gamete interaction in the porcine female tract? In: JOHNSON, L.A.; GUTHRIE, H.D. (Eds.). Boar semen preservation IV. Kansas: Allen Press Inc., 2000. p.165-172. 